\title{
The effect of sublethal concentrations of malathion on some biological parameters of the ectoparasitoid wasp, Habrobracon hebetor (Say, 1836)
}

\author{
Amin ASADI $^{1}$, Jaber KARIMI ${ }^{2 *}$, Habib ABBASIPOUR ${ }^{3}$
}

Received June 11, 2018; accepted October 29, 2018.

Delo je prispelo 11. junija 2018, sprejeto 29. oktobra 2018.

\begin{abstract}
The ectoparasitoid wasp, Habrobracon hebetor (Say, 1836) (Hym.: Braconidae) is one of the most important natural enemies of many pests in Iran. In this study, the effects of sublethal concentrations of malathion $\left(\mathrm{LC}_{10}\right.$ and $\left.\mathrm{LC}_{25}\right)$ on biological parameters of the adult wasp including parasitism percentage, male production and longevity of the parasitoid in different growth stages (larvae, pupae and adult) were investigated. The experiments were conducted at $26 \pm 1{ }^{\circ} \mathrm{C}, 60$ $\pm 5 \% \mathrm{RH}$, and 16L:8D h photoperiods. The effect of sublethal concentrations of malathion on adults was determined by exposure of wasp to insecticide, and in the case of larvae and pupae, immersion method was used. Based on the results, with the increase of toxic dose, the percentage of parasitism in adult decreased from $95.65 \%$ to $87.78 \%$, compared to the control treatment. Male production increased from $22.73 \%$ in control to $56.38 \%$ at $\mathrm{LC}_{25}$ concentration. Also, the percentage of parasitism of the malathion-impregnated wasp larvae decreased from 87.78 to $22.92 \%$, compared to the control treatment. Male production from $30.94 \%$ in the control increased to $39.63 \%$ at the $\mathrm{LC}_{25}$ concentration. In addition, the percentage of parasitism in the wasp pupae impregnated with malathion was reduced from 93.33 to $88.89 \%$, respectively. Male production increased from 22.98 in the control to $37.23 \%$ in the $\mathrm{LC}_{25}$ concentration. The data showed that pupae were more susceptible to sublethal concentrations than the larvae.
\end{abstract}

Key words: malathion; sublethal concentration; Habrobracon hebetor; biology; biological parameters

\section{IZVLEČEK}

\author{
UČINEK SUBLETALNIH KONCENTRACIJ \\ MALATIONA NA NEKATERE BIOLOŠKE \\ PARAMETRE EKTOPARAZITSKE OSICE \\ Habrobracon hebetor (Say, 1836)
}

Ektoparazitska osica Habrobracon hebetor (Say, 1836), (Hymenoptera: Braconidae) je eden izmed najpomembnejših naravnih sovražnikov mnogih škodljivih žuželk v Iranu. V raziskavi so bili preučevani učinki subletalnih koncentracij malationa $\left(\mathrm{LC}_{10}\right.$ in $\left.\mathrm{LC}_{25}\right)$ na biološke parametre odraslih osic vključno $\mathrm{Z}$ odstotkom parazitiranja, razvojem samcev in življenjsko dobo parazitoida $\mathrm{v}$ različnih razvojnih štadijih (ličinke, bube in imagi). Poskus je bil izveden pri $26 \pm 1{ }^{\circ} \mathrm{C}$, $60 \pm 5 \%$ RH in osvetlitvi $6: 8$ dan/noč. Učinek subletalnih koncentracij malationa na image je bil določen z izpostavitvijo osic insekticidu, v primeru ličink in bub je bila uporabljena metoda potapljanja. Rezultati so pokazali, da je z naraščanjem koncentracije insekticida odstotek parazitiranja upadel iz $95,65 \%$ na $87,78 \%$ v primerjavi s kontrolo. Razvoj samcev se je iz $22,73 \%$ v kontroli povečal na $56,38 \%$ pri koncentraciji $\mathrm{LC}_{25}$. Tudi odstotek parazitiranja $\mathrm{z}$ malationom impregniranih ličink osic se je zmanjšal iz $87,78 \%$ na 22,92 $\%$ v primerjavi s kontrolo. Razvoj samcev se je iz 30,94 \% v kontroli povečal na $39,63 \%$ pri koncentraciji $\mathrm{LC}_{25}$. Dodatno se je odstotek parazitiranja bub impregniranih $\mathrm{z}$ malationom zmanjšal iz 93,33 na 88,89 \%. Razvoj samcev se je povečal iz 22.98 v kontroli na $37,23 \%$ pri koncentraciji $\mathrm{LC}_{25}$. Podatki so pokazali, da so bile bube bolj občutljive na subletalne koncentracije kot ličinke.

Ključne besede: malation; subletalna koncentracija; Habrobracon hebetor; biologija; biološki parametri

\footnotetext{
1 Postgraduate MSc. Student, Department of Plant Protection, Faculty of Agricultural Sciences, Shahed University, Tehran, Iran

2 Assistant Professor, Department of Plant Protection, Faculty of Agricultural Sciences, Shahed University, Tehran, Iran; ${ }^{*}$ Correspondent author: karimi_jaber@yahoo.com

3 Professor, Department of Plant Protection, Faculty of Agricultural Sciences, Shahed University, Tehran, Iran
} 


\section{INTRODUCTION}

Most insecticides have harmful effects on non-target organisms, especially natural enemies (Croft, 1990). Biocontrol agents are commonly susceptible to insecticide applications. In recent years, integrated pest management systems attempt to use natural enemies in combination with lower doses of insecticides for pest control. The combined use of biocontrol agents and insecticides to manage pests requires adequate knowledge about the aspects and selective effects of insecticides on natural enemies (Croft, 1990; Dent, 1995; Banks \& Stark, 1998; Bajc et al., 2017; Laznik \& Trdan, 2014). Several natural enemies can be used for biological control of lepidopteran pests. Among these, Habrobracon spp. are used as effective parasitoids of different pests specially in stored products and crop plants (Navaei et al., 2002).

The bollworms, Helicoverpa spp. (Lepidoptera: Noctuidae) moths have a variety of key pests in the world that are polyphagous and have a wide range of host plants for the crops, vegetables and etc. in the world and Iran. Three species of Helicoverpa armigera (Hubner, (1808)), Heliothis viriplaca (Hufnagel, 1766) and Heliothis peltigera (Denis \& Schiffermüller, 1775) have been reported in chickpea fields of Iran. The dominant species, $H$. viriplaca is reported in the chickpea fields of most regions of Iran. Farmers every year spray one or two times to prevent damage to Helicoverpa spp. by chemical insecticides such as Carbaryl (Sevin), Malathion and Phosalone. However, some species of this genus, such as $H$. viriplaca, have shown resistance to the major types of organophosphate, carbamate, and pyrethroid insecticides (Kranthi et al., 2001; Murray et al., 2005).
Habrobracon hebetor Say is an ectoparasitoid and has been studied as a biocontrol agent of various lepidopteran pests in several countries (Gerling, 1971; Youm \& Gilstrap, 1993; Magro \& Parra, 2001). In recent years, the mass rearing program of $H$. hebetor has been initiated in Iran and it has been used to control $H$. armigera, $H$. viriplaca and Ostrinia nubilalis (Hübner, 1796) specially in different regions of Iran (Navaei et al., 2002; Rafiee-Dastjerdi, 2008; Sarmadi et al., 2010). Limited information is available on the sublethal effects of commonly used insecticides on this biocontrol agent (Rafiee-Dastjerdi et al., 2008 and 2012). Estimation of lethal and sublethal effects of pesticides on a natural enemy is necessary to recognize their effects of it (Walthal \& Stark, 1997; Stapel et al., 2000; Stark \& Banks, 2003). Demographic toxicology is usually considered to be the best way to evaluate total effects of pesticides on a target insect. So, stable population parameters have been recommended to evaluate the overall effects of pesticides, because it is based on both survivorship and fecundity parameters (Stark \& Wennergren, 1995).

Considering the importance of recognizing the susceptibility of various growth stages of parasitoid to insecticides, and in order to determine the best time to release them in the field and to perform the spraying, we try to evaluate the $H$. hebetor wasp susceptibility in the adult stages in comparison with the recommended dosage. The main objective of this study was to evaluate the sublethal effects of the malathion, commonly used insecticide against $H$. viriplaca in the chickpea fields of most regions of Iran and to determine the possibility of integrating the application of this species with insecticides in IPM program of this key pest.

\section{MATERIALS AND METHODS}

\subsection{Insects rearing}

Insects $H$. hebetor was obtained in adult stage from the insectarium in Lorestan province in Iran. The colony of $H$. hebetor was reared on $5^{\text {th }}$ instar larvae of the flour moth, Ephestia kuehniella Zeller, 1879 reared on wheat flour in semi-clear plastic boxes $(40 \times 25 \times 15 \mathrm{~cm})$ in the laboratory. Fifth instar larvae of E. kuehniella were used for both rearing the colony of wasp and applying experiments. Bioassay and rearing conditions were $26 \pm$ $1^{\circ} \mathrm{C}, 60 \pm 5 \% \mathrm{RH}$ and a photoperiod of $16: 8 \mathrm{~h}(\mathrm{~L}: \mathrm{D})$.

\subsection{Bioassay experiments}

\subsubsection{Preliminary bioassay}

Malathion (EC $57 \%$, Partonar Co., Iran) was used in this experiment. Serial dilutions were prepared and concentrations (determined after preliminary tests) ranged from 5 to $200 \mu \mathrm{l} \mathrm{l}^{-1}$ used immediately after preparation. Distilled water alone was used as a control. Contact toxicity of the insecticide was assessed on the adult, larvae and pupae of $H$. hebetor. Five concentrations of the insecticide were prepared to treat the insect. First, a number of parasitoid adult wasps were placed in a refrigerator at $+5^{\circ} \mathrm{C}$ for five minutes to freeze and do not move. Then for each concentration (treatment), 80-100 insects were used. Then using the 
POLO PC software, the concentrations of $\mathrm{LC}_{10}, \mathrm{LC}_{25}$, $\mathrm{LC}_{50}$, and $\mathrm{LC}_{90}$ were obtained. The adult, larvae and pupae of parasitoid were exposed to sublethal concentrations $\left(\mathrm{LC}_{10}\right.$ and $\left.\mathrm{LC}_{25}\right)$ and compared with the control.

\subsubsection{Effect of sublethal concentrations on the adults of $H$. hebetor}

For each concentration of malathion, three $1000 \mathrm{ml}$ plastic glasses were considered separately, then the walls of the glasses were sprayed with $\left(\mathrm{LC}_{10}=10.5\right.$ and $\mathrm{LC}_{25}=20.2 \mu \mathrm{ll}^{-1}$ ) concentrations, after the treated glasses were completely dried, in each glass, about 80 to 100 adult insects were released. After 24 hours, twenty impregnated adults (12 female and 8 male) from each glass were transferred into new $150 \mathrm{ml}$ plastic glasses, then each one was reversed on a piece of paper containing 30-days old host larvae. After 48 hours, the insects were removed and the parasitized larvae were subsequently transferred and kept in germinator at the same conditions as used for their respective parental adults. The number of parasitized larvae of the host and the percentage of parasitism was recorded. Upon emergence, the number and sex of the progeny and longevity of adults were recorded. This experiment was replicated three times for each concentration, separately. The control treatment was only with distilled water (Abedi et al., 2014).

\subsubsection{Effect of sublethal concentrations on the larvae of $H$. hebetor}

First, in order to obtain $H$. hebetor larvae, a large number of male and female wasps were randomly placed in ten clear cylindrical plastic containers $(30 \mathrm{~cm}$ height and $14 \mathrm{~cm}$ diameter) with a valve at the bottom covered with fine mesh gauze for ventilation and with a $2.5 \mathrm{~cm}$ diameter hole for feeding with $10 \%$ honey solution. Then, on five $\mathrm{A}_{4}$ size papers, a large number of E. kuehniella larvae were placed and exposed to adult parasitoids in plastic containers. After 48 hours, adult parasitoids were removed and the parasitized host larvae were kept under controlled at the same conditions as used for their respective parental adults. After appearance of $H$. hebetor larvae on the host, they were exposed to sublethal concentrations of the insecticide, so that $\mathrm{A}_{4}$ paper containing wasp larvae sticking to host larvae was cut to smaller size. On each paper cut, about 10 wasp larvae were attached to the host larvae, each cut piece was dipped separately into the insecticide solutions and immediately removed, and then the impregnated larvae were placed under rearing conditions to adult stage.
In this experiment, twenty adults ( 12 female and 8 male recognized by genitalia) emerged from impregnated larvae were transferred into new $150 \mathrm{ml}$ plastic glasses, then each one was reversed on a piece of paper containing 30-days old host larvae. After 48 hours, the insects were removed and the host larvae were kept under the same conditions as used for their respective parental adults. The number of parasitized larvae of the host and the percentage of parasitism, number of emerged males and females and longevity of adults were calculated. This experiment was replicated three times for each concentration, separately. The control was treated only with distilled water (Mahdavi et al., 2011).

\subsubsection{Effect of sublethal concentrations on the pupae of $H$. hebetor}

The rearing of a large number of $H$. hebetor pupae was carried out similar to the previous experiment for larvae. After the pupae were formed, they were exposed to sublethal concentrations, so that the paper containing the pupae was cut to smaller sizes. On each paper cut, about 40 pupae were placed, each cut was individually dipped in containers containing different concentrations of the insecticide and quickly pulled out and then the impregnated pupae were placed under rearing conditions to adult stage (Rafiee-Dastjerdi et al., 2012).

In this experiment, twenty adults (12 female and 8 male) emerged from impregnated pupae were transferred into new $150 \mathrm{ml}$ plastic glasses, then each one was reversed on a piece of paper containing 30-days old host larvae. After 48 hours, the insects were removed and the host larvae were kept under the same conditions as used for their respective parental adults. The number of parasitized larvae of the host and the percentage of parasitism, number of emerged males and females and longevity of adults were calculated. This experiment was replicated three times for each concentration, separately. The control was treated only with distilled water (Rafiee-Dastjerdi et al., 2012).

\subsubsection{Data analysis}

The biological data were submitted to analysis of variance and the means were compared by the Tukey test, using SPSS 14.0 software program (SPSS, 2004). The demographic parameters and their corresponding standard errors were estimated by the Jackknife technique (Meyer, 1986; Sokal \& Rohlf, 1981), and the means were compared by the Tukey test, using SPSS 14.0 software program (SPSS, 2004). 


\section{RESULTS}

\subsection{Effect of sublethal concentrations on the adults of $\boldsymbol{H}$. hebetor}

According to analysis variance of the the data obtained from $H$. hebetor adult, rate of parasitism percentage was found to have a significant difference at $1 \%$ level in the sublethal concentrations of malathion $\left(\mathrm{F}_{2,6}=6.7 ; \mathrm{P}\right.$ $<0.01)$. The results showed that the highest percentage of parasitism in the control treatment was $95.56 \pm$ $1.11 \%$ and the lowest in the $\mathrm{LC}_{25}$ concentration was $87.88 \pm 1.11 \%$. Also, results of $H$. hebetor male production were found to be significantly different between treatments $\left(\mathrm{F}_{2,6}=5.26 ; \mathrm{P}<0.01\right)$. The highest percentage of males was appeared in $\mathrm{LC}_{25}$ concentration that was $38.56 \pm 5.26 \%$ and the lowest in control treatment was $22.73 \pm 2.62 \%$. Also, based on the results of the analysis of variance, the adult longevity of $H$. hebetor under the influence of different concentrations of malathion was significant $\left(\mathrm{F}_{2,6}=\right.$ 20.73; $\mathrm{P}<0.01)$. The results showed that the maximum adult longevity was $16.00 \pm 0.58$ days for the control treatment and the lowest for the $\mathrm{LC}_{25}$ concentration for $10.67 \pm 0.33$ days (Table 1 ).

Table 1: Mean comparison $( \pm \mathrm{SE})$ of percentage of parasitism, male production and longevity of Habrobracon hebetor adult wasps effected by sublethal concentrations of malathion

\begin{tabular}{cccc}
\hline Concentration & Parasitism $(\%)$ & Male production (\%) & Longevity (day) \\
\hline Control & $92.22 \pm 1.11 \mathrm{a}^{*}$ & $30.94 \pm 2.17 \mathrm{a}$ & $16.67 \pm 0.88 \mathrm{a}$ \\
$\mathrm{LC}_{10}$ & $92.22 \pm 1.11 \mathrm{a}$ & $29.33 \pm 2.13 \mathrm{a}$ & $12.23 \pm 0.88 \mathrm{~b}$ \\
$\mathrm{LC}_{25}$ & $87.78 \pm 1.11 \mathrm{~b}$ & $39.63 \pm 0.37 \mathrm{~b}$ & $11.67 \pm 0.33 \mathrm{~b}$
\end{tabular}

Values within the columns followed by different letters are significantly different based on Duncan Multiple Range test.

\subsection{Effect of sublethal concentrations on the larvae of $\boldsymbol{H}$. hebetor}

According to analysis variance of the data obtained from $H$. hebetor adults emerged from impregnated larvae, rate of parasitism percentage was found to have a significant difference at $1 \%$ level in the sublethal concentrations of malathion $\left(\mathrm{F}_{2,6}=9.8 ; \mathrm{P}<0.01\right)$. The results showed that the highest percentage of parasitism in the control and $\mathrm{LC}_{10}$ treatments was $92.22 \pm 1.11 \%$ and the lowest in the $\mathrm{LC}_{25}$ concentration was $87.78 \pm$ $1.11 \%$. Also, results of $H$. hebetor male produced from impregnated larvae were found to be significantly different between treatments $\left(\mathrm{F}_{2,6}=9.83 ; \mathrm{P}<0.01\right)$. The highest percentage of males was appeared in $\mathrm{LC}_{25}$ concentration that was $39.63 \pm 0.37 \%$ and the lowest in $\mathrm{LC}_{10}$ treatment was $29.33 \pm 2.13 \%$. Also, based on the results of the analysis of variance, the longevity of $H$. hebetor adults emerged from impregnated larvae under the influence of different concentrations of malathion was significant $\left(\mathrm{F}_{2,6}=13.27 ; \mathrm{P}<0.01\right)$. The results showed that the maximum adult longevity was $16.67 \pm$ 0.88 days for the control treatment and the lowest for the $\mathrm{LC}_{25}$ concentration for $11.67 \pm 0.33$ days (Table 2).

Table 2: Mean comparison $( \pm \mathrm{SE})$ of percentage of parasitism, male production and longevity of Habrobracon hebetor adult wasps emerged from impregnated larvae effected by sublethal concentrations of Malathion

\begin{tabular}{cccc}
\hline Concentration & Parasitism $(\%)$ & Male production (\%) & Longevity (day) \\
\hline Control & $92.22 \pm 1.11 \mathrm{a}^{*}$ & $30.94 \pm 2.17 \mathrm{a}$ & $16.67 \pm 0.88 \mathrm{a}$ \\
$\mathrm{LC}_{10}$ & $92.22 \pm 1.11 \mathrm{a}$ & $29.33 \pm 2.13 \mathrm{a}$ & $12.23 \pm 0.88 \mathrm{~b}$ \\
$\mathrm{LC}_{25}$ & $87.78 \pm 1.11 \mathrm{~b}$ & $39.63 \pm 0.37 \mathrm{~b}$ & $11.67 \pm 0.33 \mathrm{~b}$
\end{tabular}

Values within the columns followed by different letters are significantly different based on Duncan Multiple Range test.

\subsection{Effect of sublethal concentrations on the pupae of $\mathrm{H}$. hebetor}

According to analysis variance of the data obtained from $H$. hebetor adults emerged from impregnated pupae, rate of parasitism was found to have a significant difference at $1 \%$ level in the sublethal concentrations of malathion $\left(\mathrm{F}_{2,6}=5.6 ; \mathrm{P}<0.01\right)$. The results showed that the highest percentage of parasitism in the control and $\mathrm{LC}_{10}$ treatments was $95.56 \pm 1.11 \%$ and the lowest in the $\mathrm{LC}_{25}$ concentration was $88.89 \pm 1.11 \%$. Also, 
results of $H$. hebetor male produced from impregnated pupae were found to be significantly different between treatments $\left(\mathrm{F}_{2,6}=34.68 ; \mathrm{P}<0.01\right)$. The highest percentage of males was appeared in $\mathrm{LC}_{25}$ concentration that was $37.12 \pm 1.49 \%$ and the lowest in control treatment was $22.98 \pm 0.53 \%$. Also, based on the results of the analysis of variance, the longevity of $H$. hebetor adults emerged from impregnated pupae under the influence of different concentrations of malathion was significant $\left(\mathrm{F}_{2,6}=11.55 ; \mathrm{P}<0.01\right)$. The results showed that the maximum adult longevity was $16.33 \pm$ 0.33 days for the control treatment and the lowest for the $\mathrm{LC}_{25}$ concentration for $12 \pm 0.58$ days (Table 3 ).

Table 3: Mean comparison $( \pm \mathrm{SE})$ of percentage of parasitism, male production and longevity of Habrobracon hebetor adult wasps emerged from impregnated pupae effected by sublethal concentrations of malathion

\begin{tabular}{cccc}
\hline Concentration & Parasitism (\%) & Male production (\%) & Longevity (day) \\
\hline Control & $93.33 \pm 1.92 \mathrm{~b}^{*}$ & $22.98 \pm 0.53 \mathrm{~b}$ & $16.33 \pm 0.33 \mathrm{a}$ \\
$\mathrm{LC}_{10}$ & $95.56 \pm 1.11 \mathrm{a}$ & $23.91 \pm 1.70 \mathrm{~b}$ & $14.33 \pm 0.88 \mathrm{a}$ \\
$\mathrm{LC}_{25}$ & $88.89 \pm 1.11 \mathrm{~b}$ & $37.12 \pm 1.49 \mathrm{a}$ & $12.00 \pm 0.58 \mathrm{~b}$
\end{tabular}

Values within the columns followed by different letters are significantly different based on Duncan Multiple Range test.

\section{DISCUSSION}

Parasitism is a practice where the parasitoid needs to have searching efficiency, eggs in the ovary, and the ability to access the host. Therefore, reducing each of the above factors can lead to reduction in the percentage of parasitism. Chemical pesticides may be more or less able to do so. In natural condition, natural enemies first find their host habitat through kairomones that comes from the plant (Blassioli-Moraes et al., 2016). According to Cloyd (2012), the smell of the insecticide and the material produced from the plant at low doses may cause confusion of the natural enemy and reduce parasitism. Although it is easy to find the host in the laboratory condition, but the smell of insecticide may lessen the ability to search and access the host. Research has also shown that some insecticides reduce the number of eggs in the ovary (Daniel, 1975). The results of our experiments showed that there is a significant difference between the percentage of parasitism of adult wasps exposed to sublethal concentrations of malathion. Parasitism rate of $H$. hebetor has increased with decreasing sublethal concentrations. The percentage of parasitism in exposed wasps at the mentioned concentrations ( $\mathrm{LC}_{25}, \mathrm{LC}_{10}$ and control) was 87.78, 92.22 and $95.56 \%$, respectively.

Rafiee-Dastjerdi et al. (2009) examined the susceptibility of the immature stages of $H$. hebetor parasitoid wasp to the pesticides in order to investigate the effect of the recommended dose of Spinosad, Profenofos, Thiodicarb and Hexaflumuron in two methods of spraying and placement on the immature stages of the wasp and the emergence of adults. Based on the International Organization for Biological Control, Profenofos, Spinosad and Thiodicarb, with a mean decrease of $73.62,39$ and $29.25 \%$, respectively, of the emergence of insects were placed in in the less toxic group and Hexaflumuron with a reduction of $87.8 \%$ in the adult emergence in the harmless insecticide group. It seems that the difference between the results of this study and Rafiei Dastjerdi et al. (2009) is due to difference in the laboratory conditions, host as well as differences in the stage of life of the wasp. Because the susceptibility of the adult stages have been studied in this study. It seems that the larval growth stage of $H$. hebetor is less affected by the sublethal concentration of the insecticide, because until the adult stage most of insecticide decomposes inside the insect's body. It also seems that due to the fact that wasp has been fed with water, honey and vitamin C until death, less fluctuations has occurred over their lifetime (Soyelu, 2013).

Results of timed bioassay of Baker et al. (1995) showed that field strain of $B$. hebetor was significantly more tolerant of malathion compared to the laboratory strain. Also, triphenyl phosphate (TPP) substantially delayed the toxicity of malathion. The results of Mahdavi \& Saber (2013) showed that malathion rather than diazinon had the lowest adverse effects on the functional response of $H$. hebetor. After conducting advanced field studies, it was found that malathion may be used as a compatible chemical material with biological control in IPM programs.

The results of this study showed that there was a significant difference between male production of $H$. hebetor adult wasps and sublethal concentrations of malathion. In the $\mathrm{LC}_{25}$ concentration, male production 
was increased in adult wasps and was reduced by decreasing sublethal concentrations. Amir-Maafi et al. (2002) stated in their study on Trissolcus grandis (Thompson, 1861) that the female wasps in the first five days lay $26 \%$ of their total eggs and $51 \%$ of the hatched eggs of the female wasp is related to its first five days of activity. Also, $63.66 \%$ of the total produced females were related to this period, but after 5 days from the evaluation period, the male production and mortality of the female wasps increased. In fact, in the male production of insecticide-exposed wasps, the age of the wasps is also important. Also, based on the growth characteristics of parasitoid wasps of the sunn pest, male parasitoids appear earlier than females and work around un-emerged parasitized eggs (Amir Majafi, 2000; Safavi, 1974; Asgari, 1996). For this reason, chemical insecticides appear to effect on male wasps and cause mating ability to reduce and inoculate the egg, resulting in the production of haploid (male) individuals.

Based on the results of the effect of sublethal concentrations of malathion on the longevity, the results were significantly different between treatments. According to the results, with the increase of sublethal dose of malathion, the longevity of $H$. hebetor progeny has decreased compared to control treatment. The results of Shishehbor and Faal-Mohammad-Ali (2013) showed that the effects of Flufenoxuron (Cascade) and Lufenuron insecticides on different stages of $H$. hebetor larvae were not significantly different in terms of longevity and egg oviposition of females. But different growth stages had a significant effect on the longevity of female parasitoid. According to their results, the highest longevity was related to the lufenuron-treated pupal stage. Interaction effects of insecticides and different growth stages did not have a significant effect on the longevity of the female. The results of our study were not similar to this study. It seems that the difference in the results is due to the type of insecticide used in the treatment. It may also be possible that reduction of longevity of the wasps at high concentrations of insecticide is due to reduction in wasp body water content. Wasps seem to need more water to eliminate toxic compounds in their body, resulting in more activity to eliminate poisonous compounds, lose their body water and die.

The results showed that the percentage of parasitism decreased with increasing sublethal concentration of malathion. The results of Faal-Mohammad-Ali et al. (2015) in evaluating the effects of chlorpyrifos and fenpropathrin in the sublethal concentration of $\mathrm{LC}_{25}$ on the parameters of stable population of $H$. hebetor parasitoid wasp in the larval stage showed that fenpropathrin insecticide had the most effect on the parameters of stable population growth. There was a significant difference between the treatments and the control. There was no significant difference between chlorpyrifos and fenpropathrin except for the population growth rate. The results of these researchers are similar to the results of the present study, and the numerical differences in the data are related to the test conditions and insecticide concentrations.

Abedi et al. (2014) evaluated the sublethal effects of azadirachtin and cypermethrin insecticide and the adult wasps were exposed to the $\mathrm{LC}_{30}$ concentration of the insecticides, and then demographic parameters of the surviving wasps were determined. Fecundity, fertility, and parameters including the intrinsic rate of increase $\left(r_{m}\right)$ were affected negatively.

\section{CONCLUSION}

Even though results obtained in small laboratory arenas may not be realized under natural conditions (Kareiva, 1990), these kinds of investigations under the laboratory conditions can be helpful in selecting insecticides for additional studies under more natural conditions and for application of suitable insecticides along with natural enemies in the pest management programs.

\section{ACKNOWLEDGEMENTS}

The work received financial support from Postgraduate Education Bureau of the Shahed University, Iran, which is greatly appreciated. 


\section{REFERENCES}

Abedi, Z., Saber, M., Gharekhani, G., Mehrvar, A., \& Kamita, S.G. (2014). Lethal and sublethal effects of azadirachtin and cypermethrin on Habrobracon hebetor (Hymenoptera: Braconidae). Journal of Economic Entomology, 107(2), 638-645. doi:10.1603/EC13227

Amir-Maafi, M., Kharazi Pakdel, A., Rasoulian, Gh., \& Sahragard, A. (2002). Efficiency and regulation mechanisms of sunn pest population, Eurygaster integriceps Put. (Het.: Scutelleridae), by egg parasitoids in Varamin. Journal of Entomological Society of Iran, 22(1), 29-47.

Bajc, N., Držaj, U., Trdan, S., Laznik, Ž. (2017). Compatibility of acaricides with entomopathogenic nematodes (Steinernema and Heterorhabditis). Nematology, 19, 891-898. doi:10.1163/1568541100003095

Baker, J.E., Weaver, D.K., Throne, J.E., \& Zettler, J.L. (1995). Resistance to Protectant Insecticides in Two Field Strains of the Stored-Product Insect Parasitoid Bracon hebetor (Hymenoptera: Braconidae). Journal of Economic Entomology, 88(3), 512-519. doi:10.1093/jee/88.3.512

Blassioli-Moraes, M.C., Borges, M., Michereff, M.F., Magalhães, D.M., \& Laumann, R.A. (2016). Semiochemicals from plants and insects on the foraging behavior of Platygastridae egg parasitoids. Pesquisa Agropecuária Brasileira, 51(5), 454-464. doi:10.1590/S0100-204X2016000500005

Banks, J.E., \& Stark, J.D. (1998). What is ecotoxicology? An ad-hoc grab bag or an interdisciplinary science? Integrative Biology. Wiley-Liss, Inc., pp. 195-204.

Cloyd, R.A. (2012). Indirect effects of pesticides on natural enemies, pp. 127-150. In: Soundararajan, R.P. [ed.]. Pesticides Advances in Chemical and Botanical Pesticides. In Tech, Rijeka, Croatia. 382 pgs. ISBN no. 978-953-51-0680-7.

Croft, B.A. (1990). Arthropod Biological Control Agents and Pesticides. John Wiley and Sons, New York.

Daniel, J.C., \& Amladi, S.R. (1975). The Nilgiri Wood Pigeon, Columba elphinstonii (Sykes) on Salsette Island, Bombay. Journal of the Bombay Natural History Society, 71, 304.

Dent, D. (1995). Integrated Pest Management. Chapman and Hall, London.

Faal-Mohammad-Ali, H., Allahyari, H., \& Saber, M. (2015). Sublethal effect of chlorpyriphos and fenpropathrin on functional response of Habrobracon $\quad$ hebetor (Hym.: $\quad$ Braconidae). Archives of Phytopathology and Plant Protection, 48(4), 288-296. doi:10.1080/03235408.2014.886411

Gerling, D. (1971). Occurrence, abundance, and efficiency of some local parasitoids attacking Spodoptera littoralis (Lepidoptera: Noctuidae) in selected cotton fields in Israel. Annales of Entomological Society of America, 64, 492-499. doi:10.1093/aesa/64.2.492

Kareiva, P. (1989). The spatial dimension in pest-enemy interactions. In: Mackauer, Ehler and Roland (ed). Critical Issues in Biological Control. Intercept, Andover, Intercept Ltd., U. K., pp. 213-227.

Kranthi, K.R., Jadhav, D., Wanjari, L.R., \& Russel, D. (2001). Pyrethroid resistance and mechanism of resistance in field strain of Helicoverpa armigera (Lepidoptera: Noctuidae). Journal of Economic Entomology, 94, 1-6. doi:10.1603/0022-049394.1.253

Laznik, Ž., \& Trdan, S. (2014). The influence of insecticides on the viability of entomopathogenic nematodes (Rhabditida: Steinernematidae and Heterorhabditidae) under laboratory conditions. Pest Management Science, 70, 784-789. doi:10.1002/ps.3614

Mahdavi, V., \& Saber, M. (2013). Functional response of Habrobracon hebetor Say (Hym.: Braconidae) to Mediterranean Flour Moth (Anagasta Kuehniella), in response to pesticides. Journal of Plant Protection Research, 53(4), 399-403. doi:10.2478/jppr-2013-0059

Mahdavi, M., Saber, M., Rafiee-Dastjerdi, H., \& Mehrvar, A. (2011). Comparative study of the population level effects of carbaryl and abamectin on larval ectoparasitoid Habrobracon hebetor Say (Hymenoptera: Braconidae). BioControl, 56, 823830. doi:10.1007/s10526-011-9356-8

Magro, S.R., \& Parra, J.R.P. (2001). Biologia do ectoparasitoide Bracon hebetor Say, 1857 (Hymenoptera: Braconidae) em sete especies de lepidopteros. Scientia Agricola, 58, 693-698. doi:10.1590/S0103-90162001000400007

Meyer, J.S., Ingersoll, C.G., McDonald, L.L., \& Boyce, M.S. (1988). Estimating uncertainty in population growth rates: Jack knife vs. bootstrap techniques. Ecology, 67, 1150-1166.

Murray, D.A.H., Lloyd, R.J., \& Hopkinson, J.E. (2005). Effective of new insecticides for management of Helicoverpa spp. (Lepidoptera: Noctuidae) in 
Australian grain crops. Australian Journal of Entomology, 44(1), 62-67. doi:10.1111/j.14406055.2005.00422.x

Navaei, A.N., Taghizadeh, M., Javanmoghaddam, H., Oskoo, T., \& Attaran, M.R. (2002). Efficiency of parasitoid wasps, Trichogramma pintoii and Habrobracon hebetor against Ostrinia nubilalis and Helicoverpa sp. on maize in Moghan. In Proceedings of the 15th Iranian Plant Protection Congress. September 7-11, Razi University of Kermanshah, Iran. [In Persian]

Rafiee-Dastjerdi, H. (2008). Studying lethal effects of thiodicarb, profenofos, spinosad and hexaflumuron on cotton bollworm and their lethal and sublethal effects on ectoparasitoid Habrobracon hebetor Say (Hymenoptera: Braconidae). Ph.D. dissertation. Tabriz University, Tabriz, Iran, 108 pp.

Rafiee-Dastjerdi, H., Hassanpour, M., Nouri-Ganbalani, G., Golizadeh, A., \& Sarmadi, S. (2012). Sublethal effects of indoxacarb, imidacloprid and deltamethrin on life table parameters of Habrobracon hebetor (Hymenoptera: Braconidae) in pupal stage treatment. Journal of Crop Protection, 1(3), 221-228.

Rafiee-Dastjerdi, H., Hejazi, M.J., Nouri-Ghanbalani, G., \& Saber, M. (2008). Toxicity of some biorational and conventional insecticides to cotton bollworm, Helicoverpa armigera (Lepidoptera: Noctuidae) and its ectoparasitoid, Habrobracon hebetor (Hymenoptera: Braconidae). Journal of Entomological Society of Iran, 28, 27-37.

Rafiee-Dastjerdi, H., Hejazi, M.J., Nouri-Ghanbalani, G., \& Saber M. 2009. Sublethal effects of some biorational and conventional insecticides on ectoparasitoid, Habrobracon hebetor Say (Hymenoptera: Braconidae). Journal of Entomology, 6, 82-89. doi:10.3923/je.2009.82.89

Sarmadi, S., Nouri-Ganbalani, G., Rafiee-Dastjerdi, H., Hassanpour, M., \& Farshbaf-Pourabad, R. (2010). The effects of Imidacloprid, Indoxacarb and Deltamethrin on some biological and demographic parameters of Habrobracon hebetor Say (Hymenoptera: Braconidae) in adult stage treatment. Munis Entomology \& Zoology, 5(2), 646-651.
Shishehbor, P., \& Faal-Mohammad-Ali, H. (2013). Study of sublethal effects of Flufenoxuron and Lufenuron insecticides on the life table parameters of Habrobracon hebetor Say (Hym.: Braconidae). Iranian Journal of Plant Protection Science, 43(2), 242-233.

Sokal, R.R., \& Rohlf, F.J. (1981). Biometry, the principles and practice of statistics in biological research. W.H. Freeman and Company, New York, $859 \mathrm{pp}$.

Soyelu, O.J. (2013). Suitability of a Novel Diet for a Parasitic Wasp, Cotesia plutellae. Journal of Insect Science, 13, 86. doi:10.1673/031.013.8601

SPSS (2004). SPSS for windows. SPSS INC., Chicago, Illinois.

Stapel, J.O., Cortesero, A.M., \& Lewis, W.J. (2000). Disruptive sublethal effects of insecticides on biological control: altered foraging ability and life span of a parasitoid after feeding on extrafloral nectar of cotton treated with systemic insecticides. Biological Control, 17, 243-249. /doi:10.1006/bcon.1999.0795

Stark, J.D., \& Banks, E. (2003). Population level effects of pesticides and other toxicants on arthropods. Annual Review of Entomology, 48, 505-519. doi:10.1146/annurev.ento.48.091801.112621

Stark, J.D., \& Wennergren, U. (1995). Can population effects of pesticides be predicted from demographic toxicological studies? Journal of Economic Entomology, $\quad 88, \quad 1089-1096$. doi:10.1093/jee/88.5.1089

Walthall, W.K., \& Stark, J.D. (1997). A comparison of acute mortality and population growth rate as endpoints of toxicological effect. Ecotoxicology and Environmental Safety, 37(1), 4552. doi:10.1006/eesa.1997.1521

Youm, O., \& Gilstrap, F.E. (1993). Life-fertility tables of Bracon hebetor Say (Hymenoptera: Braconidae) reared on Heliocheilus albipunctella de Joannis (Lepidoptera: Noctuidae). Insect Science and its Application, 14, 455-459. 